\title{
Everyday resistance and everyday order in world politics
}

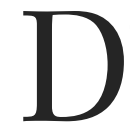
espite the increasing involvement of peacebuilding strategies in spheres of sovereign authority after the Cold War, and despite the fact that these strategies aim to reconstitute state authority, peacebuilding continues to be thought of as external to the conflicts and violent dynamics it addresses. The critical peace and conflict studies literature has challenged this vision, but in trying to understand the power dynamics in peacebuilding processes it has reified a binary vision by analysing these dynamics along an international-local axis. This vision has also reinforced the view that conflicts and their aftermaths relate to a different kind of politics and history to that of peacebuilders and peacebuilding. Resistance in this context is the ad hoc strategies of multiple local actors towards the international peacebuilders.

Throughout this book I have argued that resistance in a peacebuilding context recontextualises historical practices of mitigation and denial of domination. This domination comes not only from the international imposition of particular policies, but primarily from the reproduction of coercive and extractive practices embedded in state-making. Peacebuilding is premised on building state authority as a necessary means to achieve and consolidate peace, democracy and development. However, practice makes these aims more of a claim to legitimate authority than a manifestation of what is actually done. Peacebuilding's everyday demonstrates that the reconstitution of political authority after conflict is plural, contradictory and improvised. Everyday forms of resistance therefore provide insight into the everyday practices of institutions, norms and processes that operate transversally at local, national and international levels. This is demonstrated by how the everyday resistance strategies seen in the last three chapters target national and international actors as symbols of authority. This is also why peacebuilding cannot be seen as an external process or actor. The study of everyday resistance reveals important elements of everyday order in world politics.

Lack of attention to resistance has long provided a view of peacebuilding as overpowering and monolithic in peace and conflict studies. The turn to hybridity 
has included a focus on resistance and provided a more grounded critique of peacebuilding. But resistance remains under-theorised, given how subjects and their aims are left undefined. The everyday framework of James Scott and Michel de Certeau that this book has drawn on places the agency of resistance on subordinated subjects, on patterns in power relations and on different types of acts that are context specific. In the militarised and complex context of the DRC, practices that overtly challenge authority, whether discursively or physically, go hand in hand with practices that are covert and self-regarding, but still subversive of domination.

Theorising resistance in peacebuilding contexts is not only an important part of a critical project that seeks to provide a more nuanced and realistic account of peacebuilding: it is also a step forward in theorising resistance, which is crucial for a critical IR as a whole. This is a necessary contribution for a subject whose focus is primarily the study of power. This last chapter offers a path to that research agenda and summarises how the book as a whole has provided a step in that direction.

\section{Resistance, a relational heterogeneous practice}

Xavier Guillaume notes that '[t]he tryptic [sic] constituted by resistance, the everyday and the international does not readily fit the idealized images of the international: the realm of exceptional events conducted by states and statesmen, or their proxies' (2011: 459). As discussed in previous chapters, everyday forms of resistance are the insults, mockeries and jokes; the ways in which violence from popular militias is used as well as how popular classes find channels of re-appropriation and confront extraction. These are not just activities that take place on an everyday basis, they are a pattern. It is the realm of normality, against the realm of the exceptional, as Guillaume notes, that sets the ground of resistance. This does not mean that all of what happens in these relations can be reduced to dynamics of power and resistance, but that resistance is found in this context. Both Scott and Certeau base their account on this patterned element. Even as they place other elements at the forefront of their analyses, such as acts and intent in the case of Scott, and tactics in the case of Certeau, they both see these as recovering meaning when they become a pattern and are not just random. These patterns and the power relations in which they are embedded give heterogeneous individual and collective acts political significance.

Their heterogeneity comes from the fact that they are practised according to opportunity and context. Resistance is context dependent, and in the coercive and extractive context of the DRC it is visible in a discursive, violent and subversive form. On the whole, the framework allows us to see some overarching 
elements about subjects, objects and practices of resistance in a way that a general theoretical framework can be derived, but is not fixed.

\section{Subjecthood and agency}

Regarding the subjects, the way the everyday framework is interpreted throughout this book challenges the notion of subjects of resistance in the liberal peace debates as 'locals'. This conceptualisation of subjecthood and agency clashes with the fact that another important element in understanding what resistance is, at least from an everyday framework, is the material and symbolic inequalities that constitute relations of domination. The resistance that both Certeau and Scott describe and the subjects they focus on in their works are not members of a privileged class, they are peasants and working classes - in general, individuals and collectives in a subordinated position, both materially and symbolically.

Identifying this subordinated element in resistance has several implications. Firstly, it narrows down the account and acknowledges that it may not be possible to account for all forms of resistance from all actors under all circumstances. One of these limitations is applying the framework to governments, international organisations and members of privileged classes. This does not mean that elite resistance does not exist, nor does it mean that it would be impossible to adapt forms of elite resistance to this framework, although it would require explanation and reconfiguration of the framework. This is because resistance is not simply the act of objecting, challenging or transforming, but has to do with the aims and positionality of the subjects that carry out these actions. Scott foresaw that relations of resistance are simultaneously power relations (Scott 1985: 22-3, 1990: 45). In the same way that peasants, market sellers and cooperative members tilt at UN members and the Government for not doing anything about the conflict or for fuelling it, UN officers and Government officials launch attacks against Congolese or the 'marijuana smokers' for being lazy, uncommitted to solving their own problems and violently pursuing narrowminded village-related interests. The problem is that the power of governments, international organisations and members of privileged classes is not comparable to that of peasants, street sellers and members of popular classes. It is this element that has to be embedded into accounts of resistance and analysed.

A second implication is that placing subjecthood and agency on subordinated individuals and collectives historicises relations of domination. Though the different wars have had a great impact, subordination has a longer history. This history reflects the social and political configuration of a particular place and the dynamics that reproduce it. The everyday order in world politics, which impinges on this configuration, is at play here. In the DRC, inequality and violence have a history that goes from colonisation to the different regimes 
governing the country, most prominently, Mobutu's regime. This history has turned the DRC into an economy of extraction for the world economy whereby the DRC produces raw materials for export, and imports manufactured consumer goods. It is also a recipient of aid and a producer of debt repayments. The economic and political conditions necessary for the transformation into a service state and a social economy have not taken place. This is due as much to the Mobutu and the two Kabilas' regimes, and the way politics function in the DRC, as to the everyday international order under which these regimes have operated. The living conditions affected by war that peacebuilding strategies have not improved also have to do with this longer history. These conditions are at the root of resistance.

A final implication is that resistance becomes something embodied rather than abstract. Whether resistance requires a theory of embodiment is another matter. At a minimum it requires an account of subjecthood and agency. In the everyday framework, subjects of resistance are 'fleshed' people with a particular experience of subordination, with difficult or no access to decision-making power at the institutional level and with difficult or no access to sufficient means of living. Although the hybridity literature in liberal peace debates has explored the impact on livelihoods, material and symbolic privileges, and intersecting forms of power on individuals and groups, the tendency has been to theorise resistance in abstract macro-terms. This adds to a division in IR more generally between resistance as something public and organised, where resistance is reflected in the aims of social movements and collective transformations, as opposed to being embodied in the individuals who resist oppression on their own terms. Very few scholars have been able to link these two as sides of the same coin (Bleiker 2000; Marchand 2000; Mittelman and Chin 2000).

\section{Object, motivations and intentions}

The same way that the concept of the local hides a great variety of subjects and agencies, placing the object of resistance on the liberal peace conceals the wider spectrum of aspirations and experiences that trigger resistance. The agency of resistance comes out of an alternative agenda that motivates actors to undertake resistance acts. These may not have to do with grand ideologies, and can instead be as mundane as demanding greater protection or maintaining rent prices. On the whole, what the above reveals is that the object of resistance has to do with improved conditions of living, social justice, political and economic participatory democracy and access to land. It therefore has to do with longterm political aspirations by subordinate classes though it now uses peacebuilding discourse as a platform. This agenda permeates whatever practices of resistance are used and as such is not, as Scott argues, simply another act of resistance. What this means is that these practices always have an embedded 
idea of how things should be, and this serves both as justification and as motivation behind resistance acts.

In the DRC this ideal 'should be' works both as a claim to authority from international peacebuilders and Government and as a form of resistance. Using an ideal image of how things should be aims to hold peacebuilders to account against a picture of how things are. This allows resisters to point out what authorities should be doing, and how conditions of living are far from the promises of peacebuilders and Government. The object of resistance is visible in discursive form, but it also underpins forms of resistance such as survival and re-appropriation strategies, as well as the activities of armed groups. Motivations become a moral justification for disobedience and attacks.

In this sense, aims become the immediate rationale for a particular act. As was illustrated in previous chapters, this can be seen in not paying taxes, not having to give all the food to the military, or hiding the armed groups' weapons. The result of these aims is to deny and disobey authority, which are clear forms of resistance. This is different to, though intertwined with, the motivation for these acts in the sense that they represent an ideological vision that taxes are unjust, or that military authority is exercised in an unjust and extractive form. Denying these claims, or deploying strategies to mitigate them, are also forms of resistance. The aims and motivations go hand in hand, and they become representations of the aspirations and politics of subordinate classes.

\section{Means, acts, practices}

The means used for these objectives are infinite. That is why to simply refuse does not say much about resistance. When the use of these means or the undertaking of these acts becomes a practice, that is, a pattern in relations of domination by members of a subordinate class, it becomes resistance. Much emphasis has been placed on acts and not on the other elements of the account. Additionally, different types of acts, whether violent, overt or covert, have been seen as signs of different forms of resistance. This is added to old debates about whether resistance has to be intentional or can be unintentional, whether it has to be selfless or can be self-centred.

I have argued that means or acts can have different gradients in terms of intensity, visibility of intentionality and engagement with claims. Having different gradients provides a solution to the problem of gathering intent, its visibility and the diverse range of acts. Using the differences in Certeau and Scott, this book established two categories of acts: one inspired by Scott of claimregarding acts; and another inspired by Certeau of self-regarding acts. Thus, everyday resistance can manifest itself as an attack or direct denial against authority claims in the form of insults, mockery, armed violence or tax evasion. But it can also take the form of subversion, including redefining the ideals 
embedded in the peacebuilding discourse, using armed groups to protect oneself or mitigating the dominating effects of military rule through negotiation and creative survival. The Scottian claim-regarding practices address elite claims directly. The Certeaunian 'self-regarding' practices identify acts that deny or mitigate elite claims indirectly. These acts have the self (individual or collective) at the centre of the action. By using or ignoring the claims, subjects have the capacity to subvert these claims. Actions like entering into negotiations with the military or enacting forms of survival not only facilitate the mitigation of authoritarian forms of rule and the effects of poverty but also facilitate alternative forms of social organisation and political authority.

Africanist scholars have objected to what they see as unambiguous interpretation of certain acts as resistance embedded in the everyday framework, and in particular that of Scott. While they have provided nuanced understandings and critiques of how structures of power operate in daily life, they have also portrayed an image of subjection and an imbalanced account of power. These competing interpretations are not surprising, since power and resistance cannot be theorised with regard to independently existing facts. What has been surprising is to find a convergence of literatures seeing 'agency', 'process', 'complexity' and 'hybridisation' as limiting, with a scepticism around the possibility to account for resistance in its own right. These divergences need to be explained.

For example, in regard to discourses and mockery in particular, Achille Mbembe criticises Scott, Toulabor and, more extensively, Bakhtin. In Mbembe's articulation of post-colonial political authority, mockery, derision and popular discourses should not be seen as tools of the governed but as the banal dramatisation of political power (2001: 104). For Mbembe, the way authorities become symbolised in jokes and derision with reference to the anus, genitals, sexual intercourse, defecation or belching is evidence of power's descent to the banal, its usurpation of popular discourses and its own dramatisation (2001: 108-13). Henceforth, derision is the domain not of resistance against power but of power's own reproduction. Mbembe and Scott are not far from agreement. Mbembe's point is that post-colonial relations are too complex and muddled to be seen through a prism of categories that are based on structures that are not necessarily opposed but negotiated (1991b: 106). But Mbembe agrees that, despite these sophisticated tools of intimate and entangled power relations, oppressive structures and their subversion play a constant game of readjustment where none of them is completely able to subject or subvert the other (1988: 217). This is not dissimilar to Scott's conceptualisation of the pose, nor to Certeau's notion of trickery.

Mbembe also reminds us that the ways in which societies compose and invent themselves in the present - what we could call the creativity of practice - is always ahead of the knowledge we can ever produce about them' (Weaver Shipley 2010: 654, emphasis in the original). Any practice of resistance has to be understood as embedded in the practice of everyday life, without reducing 
daily life to a binary relation of domination and resistance. Survival strategies and non-elite re-appropriation escape rigid categorisation, but they also display elements of claims, denial/mitigation and agenda advancing present in relations of domination. These strategies facilitate non-elite denial of the state's extractive and wealth-distributive mechanisms; they mitigate multiple daily sources of oppression, including the externalities of peace strategies; and they represent self-organisational arrangements closer to alternative political agendas of participation, distribution and social service. The same way that militias are an effect of state-making, understood as the continuation of war and the militarisation of peace, survival strategies are also an effect of state-making. They have to be understood within the context of presence and absence of multiple authorities, and of their distributive and extractive capacity.

Regarding the use of violence, the book pointed out that Scott's framework is not one of peaceful resistance per se, but a framework to analyse the political significance of these quotidian practices. Because Scott's studies are not settled in a context of war, they concentrate on relatively peaceful practices. However, Scott acknowledges that even within these contexts, boycotts, hit-and-run and guerrilla tactics are habitual (1985: 241). 'Such low profile techniques', Scott argues, 'are admirably suited to the social structure of the peasantry - a class scattered across the countryside, lacking formal organization and best equipped for extended, guerrilla-style, defensive campaigns of attrition' (1985: xvi-xvii). That is, despite the use of violence, guerrilla-style tactics are not rare and they follow the patterns of other practices regarding loose organisation and avoidance of direct confrontation. Following Thandika Mkandawire, this book embraces the challenge that 'fatally flawed and morally reprehensible though these movements may be, one needs to take their political roots and ideological cognitive components seriously, even as their banditry confounds their political agenda' (2008: 107). This ambiguous ground problematises the account of resistance but unearths important nuances without imposing a Manichean vision.

The militarised context and historical dynamics of self-reliance generate interesting insights into different practices, showing that not just opposition and attack, but also reciprocity and solidarity, are important mechanisms against domination. Different practices run alongside each other, affording the possibility to observe the interplay between violence, self-defence and political aspirations for social justice. Even if the same practices may give rise to different conclusions, this analysis establishes one way to challenge uni-vocal readings of discourse, violence and survival as agencies of subjection or evidence of domination.

In Certeau, violence is hardly visible, although uses of Certeau have provoked different readings of the relationship between the framework, resistance and violence (Mitchell 2011a; Richmond 2011a). Everyday forms of resistance 
establish a framework to understand that the tendency to enact nonconfrontational and unorganised self-help practices against everyday forms of domination is connected to the ability these methods have to avoid repression. Different practices need to be seen alongside and in relation to the political context in which they are embedded.

None of these elements, regarding the subjects, object and means, nor the intensity and visibility with which they operate, is free of ambiguity. One of the advantages of the everyday framework is its capacity to visualise its own limitations and the complex relation between reality and interpretation. The fact that resistance and domination do not speak of permanent states of being but of an ongoing, changing relation requires theorising relations of domination in reference to their fluid boundaries. Daily life and its political context cannot be accounted for only by reference to a relation of domination and resistance. However, taking resistance out for being too ambiguous is to take out an essential part of power relations and everyday life. This book is evidence that resistance is not only relevant, it is a necessary category in our understanding of reality. Resistance, as Scott argues, is a prosaic presence. This is visible in the $\mathrm{DRC}$, as in other peacebuilding contexts. Yet it is precisely this prosaicness that requires from us an examination of the practices of peacebuilding through practices of state-making to understand the longer history from which resistance comes.

\section{War and peace between coercion and extraction}

Since the end of the Second World War, collective security has been articulated to prevent conflicts and threats from degenerating into the two world wars experienced in the first half of the twentieth century. Nevertheless, its practice has never been without challenges and contradictions. If interventions during the second half of the twentieth century were almost paralysed due to the Cold War, interventions at the turn of the twenty-first century have also suffered from aiming at transforming state authority while lacking sufficient means and clashing with other agendas. In the DRC, the granting of the monopoly of legitimate violence to the state, so central to peacebuilding, has been a constant source of the reproduction of violence. However, due to peacebuilding's capacity to externalise blame and claim the authority to continue operating, the strategy has not changed.

Bourdieu observes that history forecloses the multiple possibilities it brings. He notes that, at one particular time, it would have been possible not to develop nuclear energy, or to enact a fairer system of property law. Once these policies are established, however, they are seen as irreversible and unthinkable otherwise (Bourdieu 2014: 164-5). The consequence of an international system that rests on state authority means that any threats to states are a threat to the entire 
system. State-making becomes the only alternative to war and insecurity, even if core aspects of it are a cause of instability.

Defining the problem and its solution is thus evidence of the authority peacebuilders exercise. Yet, in the context of an African country, it also proves Africa's paradigmatic status as 'an object of experimentation' (Mbembe 2001: 2). In so far as 'Africa stands out as the supreme receptacle of the West's obsession with, and circular discourse about, the facts of "absence," "lack," and "non-being," it is also a paradigmatic target of interventions and policies that 'through a process of domestication and training, bring the African to where he or she can enjoy a fully human life' (Mbembe 2001: 1-2). The DRC was in fact one of the first cases in which statebuilding was attempted, and scholars have seen in new policy more of a discourse than a real undertaking (Chandler 2010a). They have linked the goals of these strategies to the broader global governance agenda, whose aims, as Duffield (2007) points out, are not the improvement of institutions and conditions of living for Global South residents, but the protection of Global Northerners from the perceived problems of the so-called South.

The outcome of over 15 years of peacebuilding in the DRC has not been the reconstruction of a democratic state but the continuation of patronage and violence (ISSSS 2013). In this sense, peacebuilding becomes a claim to legitimate authority to deploy a series of policies that reflect more on discourse than on their real outcomes. Yet its everyday practices are important to analyse, as they provide us with an understanding about how these policies have in fact reproduced issues they wanted to solve. In addition, and more importantly in our case, they help us to better understand resistance.

Drawing on a critical reading of Weberian historical sociology and through the analysis of critical Africanist scholars on the nature of political authority in Africa, the book presents state-making as defined by the practices of coercion, accumulation and legitimacy claiming. This does not fit a narrative of centralisation and institutionalisation, but it reflects patterns of violence and wealth management as sources of state authority. Following contemporary Weberian scholars, it is evident that states are far from the ideal image of organised coherent institutions depicted in peacebuilding policies (Mann 1993; Tilly 1990). Authority is drawn from the combination of the use of force and the negotiation of multiple public and private interests coming from inside and outside the state. Violence and extraction play a fundamental role in the distribution of power, privilege and wealth.

As discussed, the African state maintains an extractive and violent structure but this is not because African states have not made it yet, or because African leaders are particularly corrupt individuals. It is the combination of a series of historical events that go hand in hand with, or even ahead of, world history (Comaroff and Comaroff 2012). Although the book did not have the chance to 
deeply analyse the history of the DRC and common features of the African continent, it has pointed out that there are historical factors which need to be taken into account to understand the nature of contemporary states and wars in the continent. These include how independence largely enforced a colonial state, albeit with native leaders (Davidson 1992). They also include how the Cold War hijacked the processes of socialisation and democratisation of African states: either as violent confrontations like those in Angola and Mozambique, or as the quashing of transition processes such as those in the DRC and Burkina Faso. Added to the authoritarian regimes and economic crises of the Cold War, development strategies, and in particular the SAPs, made states go through a process of adjustment, privatisation and the dismantling of public institutions, with little left over for social services and infrastructure. The democratic aspirations that came with the end of the Cold War were shattered by wars and crises. The wars of the post-Cold War period in Africa should be seen in the longer patterns of Africa's relations with the world as well as with its own history.

The problem is that the view of peacebuilding and its actors as external to this history maintains a vision of issues in a country like the DRC as endogenous. This partial view ends up primarily focusing on the format rather than on the content. It targets so-called neopatrimonialism and personalised forms of governance, leaving untouched the terms of trade, of debt, of investments and distribution which contribute to the violent and extractive nature of the Congolese state. In fact, peacebuilding/statebuilding strategies have themselves entered logics of informal shared governance arrangements. Even though the peacebuilding discourse generates important dynamics regarding the 'pose' statebuilders need to legitimise their actions, assertion of state authority is linked to power-sharing agreements between warring parties, military strategies and political compromises. These include shared coercive and extractive capacity with foreign countries, state and non-state actors. The DRC case illustrates that state authority is seen as paramount to other post-conflict strategies like democratisation, economic reconstruction and even peace. However, it also illustrates that state authority may be represented, mediated, shared or compromised by other institutions, actors and even other competing state authorities.

This sociological understanding of peacebuilding goes beyond the hybridity accounts. It analyses how macro, micro, present and historical dynamics interrelate with patterns of continuity and change. In this book, it has offered the possibility to identify resistance practices, not only as part of the complex processes and agencies that mould and hybridise peacebuilding, but as part of a distinct relationship emerging from practices of appropriation and violence in state-making. This is not a single homogeneous process, but should be seen as a series of intersecting, improvised and second agendas that come into place from myriad of actors, whether local, national, regional or international. There are therefore many and not one state-making processes. The commonplace nature 
of resistance in state-society relations has also shown the need to "pay attention to micro-developments that are often governed by contingency but taking care to place these within broader patterns of historical development' (Hobson, Lawson, and Rosenberg 2010: 3360). The value of studying practices is to facilitate a study at the intersection of these divides across time and space.

Statebuilding has come as a priority and will succeed, whatever other liberal goals came in the liberal peace package. For Hameiri (2014), for instance, this is because forms of regulatory statehood have emerged in which states need to fulfil a series of international goals relating to risk management. This does not make statebuilding any more real in the form of actually building state institutions, but in the form of assuring the fulfilment of certain functions in regard to global security policies. However, as he also argues, this will create the contradictions that we have already seen with the Arab Spring and other uprisings. Statebuilding interventions create a tension between the way they diffuse state power while strengthening the executive branch of the state, and the popular demands for participation and equality (Hameiri 2014: 328-9). We may find here again the contradiction that Aimé Césaire has already seen. He accused colonial powers of 'holding things back' while 'the colonized want[ed] to move forward' (2000: 46). He pointed out at the time that 'it is the indigenous peoples of Africa and Asia who are demanding schools, and colonialist Europe which refuses them; that it is the African who is asking for ports and roads, and colonialist Europe which is niggardly on this score' (Césaire 2000: 46). The point is, as Scott and others have noticed, that once the promises are laid out, the ground is open for confrontation (Gilroy 1993: 134; Scott 1985).

Notwithstanding that, as Hameiri rightly points out, statebuilding is not likely to dissipate but, rather, will continue to play a global regulating role; it is also likely to continue losing legitimacy as the cornerstone for democracy, peace and development. The way popular classes interpret their rights is sharply at odds with the rhetoric and the practice of interventions and the broader function that states serve in the global political economy. What a sociological approach to peacebuilding and statebuilding explains is precisely why statebuilding will continue its course, despite suffering a crisis of legitimacy. Although legitimacy has been seen as indispensable for statebuilding, this is only limited, and instead must be seen in relation to the practices of coercion and extraction that maintain everyday order.

\section{War and political transformations in central Africa and the Great Lakes region}

Fanon's view of the Congo as Africa's revolver's trigger still holds. However, as put by Kankwenda, it is not because Congo bears Africa's military's weight, but because it has the capacity to mobilise it (2005: 362). The 1996-97 war is a perfect example. The ousting of Mobutu triggered an even larger and longer war 
of continental proportions. In the same way that Europe and the world changed with the Second World War, Africa's World War signalled significant transformations for the central and Great Lakes regions and the African continent at large. Firstly, Africa's World War consolidated a series of hegemonic centres in Angola, South Africa and what Mbembe calls the new military principalities of Rwanda, Uganda and Burundi (2000a: 277). While there is a certain balance of power between them, the different conflicts of the DRC since the mid-1990s have proved that these regimes are willing to use violence in order to secure their interests in the region. Secondly, the policies that were tested as a result of the 1996 war and the ones that followed, based on the neoliberal reconstruction of the state, have not returned to the 1960s development policies where investment was channelled largely through the state (Moyo 2009: 14-5). They have furthered a policy of private investment, which has deepened forms of private governance and shared sovereignty, weakening rather than strengthening the state (Abrahamsen and Williams 2009; Hönke 2010). The coming of new players like China and India has also meant that regimes such as the DRC have been able to bypass much of the terms embedded in the conditionality of good governance policy. Still, that has not changed the fact that wealth has continued to funnel upwards and outwards. As Prunier notes (2009), these new commercial trading actors are added to the dynamics of the US war on terror and the interest in new discoveries of oil in the Great Lakes and in the Guinea gulf. Thirdly, the war signalled African societies' long-standing struggle for democratisation and freedom, renewed at the end of the Cold War. As Prunier also notes, no one thought that the 1989 revolutions in Europe would end up affecting Africa, but they did (2009: xxxii). The end of the Cold War was not only a change in the geopolitics of aid and political alliances, it was also an opportunity for many in Africa to demand from their own elites and the external powers that sustained them the democratic changes that the end of the Cold War promised. In the words of Christopher Clapham:

Even though the spectacular collapse of the Soviet bloc and the end of the Cold War created powerful international pressures for democratisation, these have had so much apparent influence because they have been able to interact with a favourable internal climate. In many ways, indeed, a process analogous to that which led to the collapse of communism has been taking place inside many African states. This has notably involved the failure of state-centred 'development'. It was always, no doubt, optimistic to suppose that the relatively feeble structures and ideologies of postindependence statehood would be able to mould the societies which they governed in the ways that their leaders hoped ... From the later 1970s, however, they started to be challenged in earnest, a challenge which has aptly been described by JeanFrançois Bayart as 'the revenge of African societies'. In all manner of ways, the suppressed and apparently docile institutions of the governed started to subvert and in some cases to demolish the states that had been imposed on them. (1993: 430) 
All of these factors make Prunier (2009) connect the conflict not just with its past, but with the process of transformation that Africa as a whole is undergoing in the form of a second modernity. Yet the tendency to study Africa as a case of neglect, war and desperation has been prominent in articulating the causes of conflict and in neglecting an account of politics and resistance. This has been largely due to the paradigm of the failed state. The conflicts in the DRC have been seen as taking place under the guise of ethnicity, greed and mismanagement. The three major explanatory approaches to the conflict explored in this book (the resource wars, the localist and the regionalist approaches) are underpinned by the vision of the state as failed or embroidered in neopatrimonial dynamics that prevent it from turning into an accountable legitimate institution. Each of these explanations highlights important dynamics of the conflict, whether the impact of the exploitation of natural resources, the relevance of land and identity at the level of village politics or the impact of the politics of the region. However, none of these dynamics is autonomous from the others. Nor can they be seen as delinked from the longer history of the DRC and Africa, or in a way that portrays land and identity as historically unchanged and fixed.

In focusing on different forms of resistance, this book has attempted to highlight an important dynamic of the conflict that has been largely undermined. As argued, the war awakened a latent desire for change. This did not trigger the formation of large social movements, although it did trigger the self-management of many villages under self-defence militias. The problem is that these militias have not been an example of ethical struggle or management. Scholars and policy-makers alike have denied a political element to many of these forms of resistance. And yet, as conflict in the DRC continues, a political response to the different actors, including popular classes, is an imperative.

Interestingly, the challenge posed by the context of peacebuilding and the DRC highlighted a convergence of several literatures with implications for the study of resistance. To liberal peace debates and the political sociology literature on statebuilding, it has highlighted the importance of accounting for the practices of accumulation and coercion embedded in state-making. Resistance in these literatures needs to find a place in its own right, rather than being an instrument for hybridising or moulding liberal interventions. Regarding peacebuilding, the DRC illustrates the reconstruction of state authority as mediated by different national, international, state and non-state actors. This mediation has fostered the pursuit of state security agendas through formulas of shared sovereignty, proxy wars through militias and a militarisation of extractive capacity. These formulas have created a contradiction between the aim of reconstituting state authority and the aim of furthering peace. This contradiction responds partly to accommodate the interests of Rwanda and allies in the region, as well 
as to the perception that the instability of the region is primarily due to the DRC as a failed state.

It is difficult to ascertain what the future of the DRC will look, but it is possible to see several transformations and continuities in the short term. Firstly, this context will be marked by a broader transformation that the entire region is undergoing, as Prunier has identified. However, the new modernising process has not only governments, investors and power dynamics as main actors, but also newly created social movements representing a trend in Africa and the world at large. Although we know more about Tunisia, Tahir Square or the Occupy movement, similar social movements across Africa have been at the forefront of a series of uprisings since the mid-2000s (Branch and Mampilly 2015). One of the characteristics of these movements is that they aim at deep social transformations rather than being focused on single-issue campaigns. The DRC has been part of this wave, with organisations like the Lutte pour le Changement (LUCHA), created in Goma in 2012, or the movement Filimbi, created in 2015 (Iñiguez de Heredia 2014; Telema 2015). They are largely urban youth movements demanding political reform, democracy, development and social justice. These and other traditional civil society organisations have been at the forefront of a campaign demanding President Kabila to step down at the end of his mandate in November 2016.

The DRC constitution allows for the renewal of the president's mandate only once, therefore Kabila cannot run for a third term. Rather than clearly stating that he will abide by the constitution and that he will organise presidential elections by the date they are due, Kabila has been creating a chaotic situation in what looks like a bid to stay in power, with massive protests in January 2015 after his decision to redo the census (Guardian 2015). Although these protests managed to stop what would have meant the delay of elections for over three years, repression against dissidents and critics has continued. Members of the opposition, youth groups, civil society and journalists have been arrested without judicial process, placed in isolation regimes, are currently disappeared or have had to seek exile (Amnesty International 2015; Boisselet 2015). Kabila's call for a dialogue with the opposition has been rejected as a manoeuvre to delay elections. The issue is that unless Kabila states openly his commitment to step down, a crisis is likely to ensue. Whether this will end up in a Burkina-Faso-type of scenario, where the government will be ousted after a short popular uprising, or there will be a Burundi-type scenario, where the country will experience another period of conflict and repression, is yet to be seen.

What we do know is that there are still parts of the DRC suffering from armed conflict, and a crisis like this will only fuel it. In any case, none of these transformations is likely to change the patterns in conflict, failed negotiations and military strategies that we have seen in the last 10 years and that have been unable to put a stop to the conflict. Neither are we likely to see a change in those 
longer patterns of extraction and coercion that prevent social justice in the DRC. After over 15 years of peacebuilding strategies and two decades of conflict, the DRC, its neighbours and popular militias are yet to establish real political negotiations. These have also been undermined by international donors' disregard for regional politics and by an increasingly authoritarian Congolese state. In the short term, meaningful political negotiations could address immediate demands regarding the proxy wars taking place, the policy towards refugees and the opening of a dialogue around land and representation. In the long term, these will be far from addressing the demands for participation and dignity of the popular classes in the DRC. The context is thus a continued trigger factor for everyday forms of resistance, whether violent or non-violent, and eventually, as we are starting to see, a pathway to greater social movements.

\section{Reflections and openings}

The focus on resistance is a way of opening a debate. Embracing its ambiguities and complexities entails entering a multidisciplinary and long-standing intellectual discussion. The study of resistance is just beginning to be established as an integral part of debates in post-conflict statebuilding and peacebuilding. A first step has been to establish that exploring resistance is an important part of providing a more nuanced, realistic and critical account of peacebuilding. The next step therefore is to have a more nuanced and critical account of resistance. This book has provided the ground for such an account and argued which core elements it should be concerned with. Different avenues may come to light with the comparison of more case studies, or with a comparison with other frameworks. There is ample scope to compare how more overt and organised practices of resistance relate to the more covert and uncoordinated ones under different frameworks. This has to do not just with the particular conceptual standpoint used to account for resistance, but also, with the need to gradate and categorise its practices.

The focus on resistance in the liberal peace debates has implications for how resistance is theorised in IR. As in the liberal peace debates, in IR, despite significant attention to resistance, there have been few attempts to systematically theorise it (Bleiker 2000; Marchand 2000; Mittelman and Chin 2000). Richmond has attempted to make this connection by adapting his work on resistance in peacebuilding to theorising resistance in IR. However, the theory of resistance that Richmond proposes fails again to historicise the everyday and to materialise the subjects of resistance. His Foucauldian-postcolonial everyday approach sees resistance as critical agency that does not just hold power to account, but that also offers a real transformative agency as a hidden everyday force (Richmond 2011 b: 422). This transformation is neither 'governmentalism' nor 'revolution' but one that 'produces a state that is representative and accountable' (Richmond 
2011b: 431). Here again, the 'hybrid' outcome of a 'representative and accountable state' is above an account of resistance. The dynamism of power relations is made static by the possibility of achieving a common good between resisters and their targets.

The everyday framework offers the possibility to observe the commonplace presence of resistance, even when forms of conscious and organised activism are absent. Its study of practices makes the everyday framework well attuned to capture the ambiguities of power and resistance relations. One of the most important insights from examining resistance in the liberal peace debates is that resistance, whether in peacebuilding, globalisation or other processes, is not a special kind, rooted in an international/local contention. Rather, resistance should be seen as stemming from historical relations of domination that are experienced in everyday life, and that are co-created nationally and internationally. This is not a reification of unhelpful divides. It is precisely the nuanced ways in which the study of everyday practices captures the interconnections and coconstitution of structure and agency, discourse and practice, material and symbolic elements, and micro and macro dynamics that allow us to break with these divides.

The everyday framework has much to contribute to help IR to go beyond these limitations. Aggie Hirst argues that "the emergent scholarship [on resistance] suffer[s] from a common problem in that the forms of resistance they conceptualise are highly susceptible to appropriation by, or reinscription within, prevailing forms of global ordering' (2015: 7). The resistant subject Hirst calls for is 'an auto-deconstructionist actor committed to viewing her own subjecthood, as well as her concrete interventions, as a site of political struggle' (2015: 7). Moving from the analytical to the normative account of resistance is a necessary exercise, but one that does not automatically happen. Hirst does not go into the debates around intent, her account points to a conscious resistance against the violence, hierarchies and exclusions embedded in global politics. This may indeed be the way resistance is more effective, but it does not constitute the only form of resistance there is.

The book has not accounted for forms of resistance as a route towards political change in the form that Richmond or Hirst have proposed. The implication, however, is not that the study of resistance is empty of ethical forms of activism or revolutionary capacity. Indeed, an important insight from this research has been that, despite the war environment and the dominating effects of statemaking, popular aspirations for justice and well-being not only do not go away, they become even more relevant. The argument advanced is that resistance cannot be accounted for in Manichean ways. After all, 'there are not good subjects of resistance' (Colin Gordon cited in Scott 1985: vii). Staying away from analyses along the 'unmanly' divides of 'good' and 'evil' is to recognise the contradictions embedded in social and political action (Nietzsche 1997: 100). 
Manichean analyses, as Mbembe argues, have a particular legacy in Africa, as part of 'a moral economy - whose power of falsification derives from its opaque ties with the cult of suffering and victimization' (2002: 630). The implication is, Mbembe continues, that the 'African subject cannot express him- or herself in the world other than as a wounded and traumatized subject' (2002: 630). The intention of the book is to contribute to a breaking up of these divides. This does not mean a rejection of an ethical commitment to research, but it does seek to 'avoid the philosophical pathology of demanding that the world reflect our conception of it' (Hoover and Iñiguez de Heredia 2011: 191).

What these millenarian anthozoans of resistance mean for the realisation of the agendas of social justice embedded in its practice is another matter (cf. Scott 1985: xvii). In wondering whether the DRC might have a 'Tahir Square moment', Stearns argues that the main obstacle to such a moment taking place is lack of leadership, whether on the part of the political opposition or on the part of social movements to channel support around them and build 'social capital' (2012d). Everyday forms of resistance are the 'social capital' of revolution, but they cannot be theorised as if they mattered only if they work towards it. Nonetheless, it would be a disservice to the analysis to end with the idea that everyday forms of resistance do not change anything. They do. They are the microscopic reworking of political and social order. As Certeau states 'The actual order of things is precisely what "popular" tactics turn to their own ends, without any illusion that it will change any time soon' (1984: 26). Everyday forms of resistance rework meanings, advance agendas, place limitations on how domination is imposed and create alternative forms of social organisation and political authority. These may not be enough to stop war, change the government and the rules of international political economy, but they are an essential basis for more meaningful social and political order. 